\title{
Dr. Brasilia and Mr. Nacala: the apparent duality behind the Brazilian state-capital nexus*
}

TOMASO FERRANDO**

RESUMO: Em agosto de 2010 o Brasil decidiu limitar os investimentos diretos estrangeiros (IDE) em terra, e atraiu a atenção de políticos, tanto quanto os temores de empresários. No entanto, alguns meses antes, em setembro de 2009, havia sido concluído um acordo trilateral com o Japão e Moçambique para implementar o agronegócio e um contrato de produção agrícola em uma área de dez milhões de hectares na região de Nacala. À luz disso, $\mathrm{o}$ artigo analisa a aparente dualidade da política brasileira, e conclui que, exatamente como no caso do romance de Robert Louis Stevenson, não é uma questão de patologia, mas uma dupla personalidade induzida voluntariamente que é estratégica para posicionar o Brasil no centro do sistema capitalista global.

PALAVRAS-CHAVE: Brasil; Moçambique; ProSavana; grilagem de terras; Cooperação SulSul; nexo capital/estado; capitalismo global.

ABSTRACT: In August 2010 Brazil decided to limit foreign direct investments (FDIs) in land, and attracted the attention of politicians as much as the fears of businessmen. However, few months before, in September 2009, it had concluded a trilateral agreement with Japan and Mozambique to implement agribusiness and contract farming on an area of ten million hectares in the Mozambican region of Nacala. In light of that, the paper analyses the apparent duality of the Brazilian politics, and concludes that, exactly like in the case of the novel by Robert Louis Stevenson, it is not a matter of pathology, but a voluntarily induced double personality which is strategic in positioning Brazil at the core of the global capitalist system. KEYWORDS: Brazil; Mozambique; ProSavana; land grabbing; South-South cooperation; state/capital nexus; global capitalism.

JEL classification: F02.

\footnotetext{
* The author is a PhD Candidate at Sciences Po Law School.

** Resident Fellow, Institute for Global Law and Policy (IGL\&P) Harvard Law School. E-mail tomaso. ferrando@sciencespo.fr. Submetido: 7/Julho/2013; Aprovado: 11/Agosto/2014.
} 
During L'Aquila G8 Summit in July 2009, the Brazilian President Lula signed a bilateral agreement with Japan to "develop agriculture in African tropical savannahs through Japanese-Brazilian cooperation by building on the achievements of the Cerrado agricultural development cooperation" (Hosono, 2012, p. 43). Few months later, the two partners officially identified Mozambique as the 'beneficiary state' of their developmental desires, and the 10 millions hectares of the Nacala Corridor as the area chosen to 'receive' one of the biggest agricultural transformation in the history of development aid. On that day, the ProSavana program was born. ${ }^{1}$

Back at home, and less the one year later, in September 2010, President Lula approved a new legal opinion of the Brazilian General Attorney Office (AGU) which extended the scope of the existing limits to acquisition of national land by foreigners. ${ }^{2}$ Legitimized by a political and media campaign that identified foreign acquisitions as land grabbing and therefore as a direct attack to national sovereignty, Lula's decision imposed the proprietary restrictions contained in law 7509/1971 also to those Brazilian companies whose majority was held by foreigners. Few months after having agreed to a privately driven developmental project finalized to the establishment of foreign agribusiness in Mozambique, the Brazilian executive was exercising its authority to oppose foreign investments in land.

The analysis of the double identity of the Brazilian government, which as Dr. Jeckill refuses land acquisitions at home, but as Mr. Hyde supports corporate and geo-strategic interests behind South-South cooperation, represents the core of this article, whose final aim is to expose some of the dark aspects which may lurk behind the idea of the New Developmental State (NDS) (Trubek et al., 2013) along with the increasing role of the Brazilian State is playing as broker of capital accumulation. Rather than pursuing an inclusive and sustainable improvement of social conditions, the Brazilian attitude appears a post-modern representation of Lefebvre's "State Mode of Production," i.e., of the use of state power to manage and maintain the capitalist growth at all spatial scales, from the local to the worldwide (Brenner, Neil \& Stuart Elden, 2009).

In order to achieve its objective, the article applies the notion of 'the return of the Brazilian State' to the case of 'global land grabbing', which is here broadly defined as the

'ongoing and accelerating change in the meaning and use of the land and its associated resources (like water) from small-scale, labour-intensive uses like peasant farming for household consumption and local markets, toward large-scale, capital-intensive, resource-depleting uses such as in-

\footnotetext{
${ }^{1}$ ProSavana is the short name for the Agricultural Development in Mozambique agreement (ProSAVANAJBM) which was signed by the Japan International Cooperation Agency (JICA), the Brazilian Cooperation Agency (ABC) and the Ministry of Agriculture of Mozambique (MINAG).

${ }^{2}$ Legal Opinion CGU/AGU n ${ }^{\circ}$ 01/2008, published in the DOU (Diário Oficial da União - Official Gazette of the Union) $n^{\circ} 161$ of August 23, 2010 under the reference AGU/LA01/2008.
} 
dustrial monocultures, raw material extraction, and large-scale hydropower generation - integrated into a growing infrastructure that link extractive frontiers to metropolitan areas and foreign markets. (Franco et al., 2013, pp. 3-4)

Even without addressing the problems related to the existence of conflicting definitions of the problem and to the absence of reliable data around the global enclosure of land (Oya, 2013; Edelman, 2013), it is evident that financial volatility, climate change, increase in the population, changes in the dietary habits of million of people, and other contemporary global issue have increased the political and strategic value of controlling land. Having exclusive access and management of a scarce and precious resource that cannot be reproduced is a form of power that goes beyond the value that land has for production: It means to have a comparative advantage against competitors and a reduced dependence on the market. For that reason, states and investors from all over the world have been increasingly participating in a global rush to the land, a geo-strategic competition where capital, diplomacy and authority are often exercised to guarantee the consolidation of individual interests and the accumulation of private capital. What this paper claims, is that Brazil does not want to lag behind.

As Saskia Sassen (2013a) recently highlighted, the study of 'land grabbing' has a heuristic effect because it exposes the role and responsibilities of the different actors involved, included the country where the investment is originating from (source country $)^{3}$ and the country where the money is directed (target country). Moreover, there is no other global phenomenon that can better demonstrate the territorial/local link of capital accumulation, and unmask the fundamental role that the State plays in facilitating and enhancing the dispossession of common goods and their passage from the public sphere to the private realm. In this optic, the case of Brazil, ${ }^{4}$ an emerging country which has been positioning itself as a bridge between the North and the South, a semi-peripheral country that defends itself from foreign investments in land and promotes large scale investments in land abroad, represents one of the clearest examples of the use of public prerogatives to play the game of global capitalism.

Brazil has been a recipient of FDIs for decades, a condition that has led to what David Harvey (2003) would define as an over-accumulation of capital. Thus, if on the one side the government is trying to protect capitals that have accumulated within, on the other side it looks beyond its frontiers for new cheap resources where investments can be directed. According to this reading, these two movements, these

\footnotetext{
${ }^{3}$ See $\mathbb{S}$ V.

${ }^{4}$ When I use the term 'Brazil', or 'Brasilia', 'State', 'Authority', etc., I do not imply that the public bureaucracy is composed by a monolithic entity with a unique voice. Rather, I use the term in a general way to identify whoever holds sovereignty as the internal and external legitimate authority which can be exercised to shape the legal and social reality both on a national level (by providing incentives, legal reforms, exemptions, etc.) both at the international level (by means of diplomatic activity and international conventions).
} 
internal/external binomial that takes the form of the GUA legal opinion and of the ProSavana project, cannot be seen as separated nor contradictory, but rather as complementary representations of the construction of Brazil as a bourgeois capitalist state and a player in the global struggle for regional control.

As desired by the Brazilian industrial base at the moment of Lula's election (Trubek et al., 2013), the 'return of the Brazilian state' which was functional to the deepening of the process of internal capitalist accumulation, is now exercising its functions and power to help the transnationalization and globalization of capital. At first, Brasilia (intended as the government) utilized its authority to create, correct and direct the internal market, and has recently entered the last of the four phases of capitalist state production as identified by Van Apeldoorn et al. (2012), a phase where national and international prerogatives are deployed to internationalizes capital (Cox, 1987) through 'external mercantile representation' (Gerstenberger, 1973).

In light of that, the paper is organized as follows. First section I provides a brief introduction of 'land grabbing' as a complex, dynamic and political concept; second section looks at the Brazilian efforts to impede the foreignization of its land; third section unpacks the ProSavana development project and critically defines it as development investment likely to 'smuggle' foreign capital and strengthen foreign control over Mozambican land (Sassen, 2013b); finally, the last section elaborates the apparent schizophrenia of Brasilia, and formulates questions and hypotheses which do not concern Brazil and Mozambique only.

\section{DR. JACKILL: THE ANTI-FOREGNIZATION MOVE OF THE BRAZILIAN GOVERNMENT}

Starting from 2006, the Brazilian national press, the Brazilian politicians and several social movements and Non-Governmental Organizations (NGOs) began instilling the idea that a foreign attack against Brazilian land was ongoing. The first claims were about Australian, Arab and Argentinean investors acquiring national land, and these actors were immediately identified as the responsible for the rapid surge in the value of the land. Rapidly, foreign investors were transformed into a Brazilian nightmare, the new scandal that required a fast and strong response from the State. Thus, government representatives met in the 'Casa Civil' in 2007, and stressed the national interest behind the reject of foreign acquisitions of land (Wilkinson, 2011). Since then, the government began a campaign to defend food security and maintaining land in Brazilian hands, as evident in declarations like "We do not need foreigners to produce food in Brazil," or "investing in land is not the same of investing in the products it generates," and that "This is the policy of President Lula da Silva." The State,

\footnotetext{
${ }^{5}$ In 2010 Lula affirmed that "[land ownership] is a problem that we have to start tackling. One thing is a citizen who comes and buys a factory, a production site. A different situation is if he wants to buy the land where the factory is built, the land to produce soya, the land for mining operations". Source:
} 
the media, some NGOs and Brazilian businessmen were all releasing similar nationalistic statements, and cooperating in protection of the status quo.

For example, when Glauber Silveira, President of the Association of soybeans Producers (APROSOJA) took office, he affirmed that "even if it is advantageous for the producer with a land leasehold, the foreign thrust is worrisome, as it pushes the Brazilian competitor away from the business and allows the territorial occupation of Brazil." Similarly, national newspapers published article where it was possible to read that "China buys land in Brazil" and that while "Foreign investments are welcome as a rule and may make important contributions to the country's growth [...] 'businesses' undergo a change of meaning when the investments are subordinated to the strategic reasons of a foreign State. In the cases of natural resources and agriculture-land, a proper evaluation of such strategy becomes a security-issue" (Sauer \& Pereira Leite, 2011).

Then, 2010 arrived and the position of the government officially shifted from that of Brazil as "perfectly able to attract investment from the Arab world" and considered a victory the fact that the Libya deputy prime minister had recently announced a US\$ 500 million investment in the Brazilian agricultural sector (Rocha, 2010), that of a country where foreign investors were no more a resource, but a threat to be defeated. To seal this transition, on August 23 $3^{\text {rd }} 2010$ the Brazilian General Attorney Office (AGU) issued a new opinion ${ }^{6}$ on foreign access to Brazilian land, which became immediately binding for all the governmental bodies, administrative agencies and all entities which are directly subject to the Executive branch, such as INCRA (Brazilian Agrarian Reform Agency), ${ }^{7}$ along with public (publicly owned) banks and enterprises. Opinion No. 01/2008-RVJ was subsequently approved by the then President Lula, and became binding on the Federal Government pursuant to section 40 of Complementary Law No. 73 of 1993.

However, the force of the political campaign was such to overemphasize the effect of the opinion. Described as 'new', it represented a return to the past traced during the Brazilian dictatorship, and was much less a bold step in defense of Brazilian sovereignty than it was portrayed. ${ }^{8}$ As a matter of fact, the opinion did not introduced a radical prohibition, but submitted foreign-owned Brazilian companies to the control and authorization of the INCRA, which were already applicable to foreign entities and individuals. In practice, despite being contested since

Folha de São Paulo, "Lula defende inibir venda de terras a estrangeiros", June 8, 2010, author's translation. Available at http://www.commercialpressuresonland.org/press/lula-defende-inibir-venda-deterras-estrangeiros [last visited February $27^{\text {th }}, 2014$ ].

${ }^{6}$ Supra n 2 .

${ }^{7}$ INCRA is the "Instituto Nacional de Colonização e Reforma Agrária" or in English, the Brazilian Institute for the Agrarian Reform.

${ }^{8}$ Wagner Rossi, former Minister of Agriculture, affirmed that "some of these countries are great partners in other areas, but having them buying land in Brazil creates some sort of sovereign risk for us. This is not part of our plan and we are not going to allow that". Source: International Business Times, 2011. 
its introduction and accused of being unconstitutional (Daiuto \& Almeida Lobo, 2011) and despite the general consensus among the social movements and the NGOs, the AGU's decision did not comport such a high obstacle to foreign investors as it was pretended.

Legally speaking, the 2010 'new' opinion states that section 1 paragraph 1 of Law No. 5,709 had never been revoked, since articles 170 "I", 172 and 190 of the Constitution already allowed restrictions on the participation of foreigners in certain activities. In practice, what that means is that Brazilian companies whose majority is owned by foreigners are submitted to the same limitations that already applicable to full foreign ownership. Thus, despite the anti-foreigners campaign and the intense debate about foods security and national control of land, the reform did not introduce any ban against foreign ownership of land, but only increased the number of companies that have to obtain the authorization from the INCRA whenever they intend to acquire land between three to one-hundred modules, with a limit represented by the fact that the same company cannot own land that exceeds one quarter of the area of the city where the properties are located.

When it came to regulation, the political campaign structured around food security and the need of preserving the Brazilian ownership of land, which had been capable of obtaining the support of national and international progressive thinkers, was reduced to some procedural requirements and qualitative and quantitative limits that can be easily eluded. Moreover, and that is the most interesting part, Lula's administration functionally selected a narrow and nationalistic definition of land grabbing that exclusively stresses the foreign control over national land, rather than the concentration of land itself. The grab was presented as a question of attack to sovereignty and independence, and not as a matter of struggle between small-scale and large-scale, or of socio-economic transformation. Issues of access and redistribution where dismissed, and the political struggle neutralized. In addition, the political 'xenophobia' should surprise even more in light of the statistics, according to which in 2010 foreigners owned 34,371 properties in Brazil, for a total amount of 4,3 millions ha, i.e., $0,70 \%$ of rural properties (Fundación Pensar, 2011). Were thus the foreigners the real threat for Brazilian food security?

The simple answer is 'not', or 'not only', but there is something more. The weakness and ambivalence of the legal response on one side, and the relative irrelevance of foreign ownership compared to the national latifundio on the other side, are evidence that the political and economic objective of Brasilia was not that of fighting land grabbing per se. Rather, the pro-agribusiness measures adopted within Brazil and the strategy adopted by the Brazilian administration outside of the national territory are revelatory of a different intention, that to consolidate capital at home and at the same time represent it abroad. In that sense, the Brazilian intervention in the North of Mozambique and the ProSavana project are emblematic. 


\section{MR. HYDE: THE BRAZILIAN INVOLVEMENT \\ IN THE PROSAVANA PROJECT IN MOZAMBIQUE}

During the L'Aquila G8 Summit in July 2009, an agreement was reached between the Brazilian and Japanese governments to "develop agriculture in African tropical savannahs through Japanese-Brazilian cooperation by building on the achievements of the Cerrado agricultural development cooperation" (Hosono, 2012, p. 43). However, no African country was present at that meeting. It was only on $17^{\text {th }}$ September 2009, when the Agricultural Development in Mozambique Agreement (ProSAVANA-JBM) was signed among the Japan International Cooperation Agency (JICA), the Brazilian Cooperation Agency (ABC) and the Ministry of Agriculture of Mozambique (MINAG), that 'African tropical savannahs' were identified as the North of Mozambique, and more precisely as the Nacala Corridor. That date signed the birth of the ProSavana project, ${ }^{9}$ and of the idea to structure a US\$ 2 billion private equity fund incorporated in Luxembourg to raise private and public money finalized to transform the agricultural structure of the Africa region.

The Nacala Corridor, situated between parallels 13 and 17 south, in the northern part of Mozambique, was identified as the 'beneficiary' area, mainly because of internal and comparative reasons. From the perspective of the developers, the region had the appropriate climate for specific types of agricultural production (Embrapa, 2012) and, more importantly, a large arable area of 14.2 million hectares - about three times the total farmland in Japan- (Funada-Classen, 2013), suitable for full mechanization. Japan and Brazil had decided that the North of Mozambique would have been transformed into the new basket of the global agricultural production, but Mozambican people only discovered that when the agreement had already been signed.

As expected, especially in light of the incredible extension of the project and of the mounting concerns around land grabbing in Africa, as soon as the project became public it was immediately attacked by local farmers and local associations, mainly because of the lack of transparency, the 'grabbing' potential, and the consequences over the life of small-hold farmers. As I discuss below, the rapid and effective creation of an unprecedented triangular network of protest and solidarity formed by communities, activists, and academics from the three countries, forced the States and their development branches to redefine their original positions on the project, but was not capable of halting the process. Some of the justifications underlying the project were changed, and a narrow interpretation of the idea of 'land grabbing' was adopted as term of reference, so that the main points of private development, agro-industrialization and cash-crop production would not be challenged (Funada-Classen, 2013). As evidence, in the moment when this article goes to press, few sporadic and ephemeral moments of public participation have been officially offered to the affected communities and their supporters in the three States,

\footnotetext{
${ }^{9}$ Technically, the name of ProSavana is "Triangular Cooperation for Agricultural Development of the Tropical Savannah in Mozambique.”
} 
and they are more the consequence of national and international pressure rather than of the spontaneous decision of the developers to define the future of Mozambique together with its people.

As a reaction to the critiques originating from representatives of the civil society in all the States involved, new counter-arguments were created to refuse the arguments raised by the people of Mozambique, with the main intention to confute the idea that ProSavana would determine any form of land appropriation. Each State endeavored in the attempt to reject the attacks that were originating from within, each of one trying to justify their involvement in the project and the national and international benefits that may be generated. In the case of Brazil, for example, the government and the supporters of ProSavana had to deal with the accuse that ProSavana would produce a Brazilian invasion of Mozambique land, a scenario that would certainly be inconsistent with the internal efforts to protect sovereignty by reducing the foreignization of the land.

In general, the first four years of life of the project have been characterized by a continuous struggle between the three governments and their business representatives, on the one side, and their communities and civil society, on the other side. However, the diffused attitude of the States and of their development agencies has been that of technical superiority and expertise vis-à-vis their counterparts, which in some cases have assumed the tones of verbal aggressions rather than providing effective and detailed responses to the people's concerns. In particular, the supporters of ProSavana have adopted different strategies in different occasions: They have simplistically dismissed the critiques as myths or lies (Fingerman, 2013), ${ }^{10}$ or even defined as void arguments produced by foreigners that could not originate from the illiterate Mozambican farmers (Japan Today, 2013): They have adopted a formalistic argument according to which there will not be land grabbing because the land belongs to the Mozambican state; ${ }^{11}$ They have stressed that a technical cooperation has no political nature; And they have also affirmed that there is not an official political support from the Brazilian government to the internationalization of its national capital, as 'land grabbing' was generally declared as state should do with war (Daimas Paiva, 2013).

In light of that, the next part of the paper reasons on these counter-arguments in order to unmask them. The aim is to demonstrate the inconsistency behind these defensive claims, and to expose the close relationship between ProSavana and the grabbing of Mozambican land. In this way, it becomes possible to expose the Brazilian interest behind the project, and the functional nature of the Brazilian duality vis-à-vis foreign investments in land within and without its borders. In particular, I discuss: a) the likelihood that ProSavana will produce land grabbing;

\footnotetext{
${ }^{10}$ Natalia Fingerman is an associate Researcher at the Brazilian Institute of Economic and Social Studies. In her piece (2013) she affirms that "there is, in reality, the construction of myths around the program. Contrary to what is generally said, I perceived that ProSavana does not implies, in no document, the grab of the land which belongs to small scale farmers, nor restricts their activities."

${ }^{11}$ Statement by the chairman of SLC Agricola, which aims at acquiring 140,000 hectares of land abroad. Available at http://www.agrimoney.com/news/brazil-farmer-turns-tables-by-seeing-land-abroad — 4146.html.
} 
b) whether the entire project will determine a Brazilian invasion of Mozambican land with the direct or indirect support of Brasilia.

\section{a) Will Mozambican land be grabbed?}

According to the official position of the Mozambican government, ProSavana will not deprive farmers of land (All Africa, 2012). However, there is little doubt that a project realized over an area of 10 million hectares where almost 3,5 million people live, will occupy spaces which are currently occupied and worked by the local communities. It all depends on words and their definition. And in the case of ProSavana, as demonstrated by the Master Plan which was leaked at the beginning of $2013,{ }^{12}$ "available land [...] does not exactly mean truly free lands where nobody claims the right of use or its occupancy. Instead, the term only stands for the mass of lands that can potentially be made available for investment projects relatively easier than other areas." 13 Thus, despite the Plan's claim that "The existence of local people's traditional rights of access to land, forest, water and other natural resources is never ignored," 14 and in contrast with the formalistic claim of legally empty public land, it appears evident that the various projects will occupy areas where people live and their rights exist. An inevitable consequence of ProSavana will be, therefore, the need to resettle people, or to occupy land where communities are not living but have traditional rights.

However, is it the occupation of titled land a form of land grabbing? If we adopt a very narrow definition which considers as grabbing the sole violent removal with no compensation - which is the one which is proposed by some big players like the World Bank, ProSavana is more likely not to generate grabbing. However, if we expand our notion of land grabbing and we consider, for example, that there will be eviction with some form of compensation (probably economic), that the projects will have an impact over water resources, generate pollution, affect biodiversity, generate the shift from biodiversity to monoculture, and that a top-down imposed reconfiguration of the entire agricultural structure will take place, it is hard to be so naïve to deny the relationship between ProSavana and land grabbing.

Moreover, the myth is not that of the possibility of relaunching small-hold farming, as requested by the communities, but the idea that it is possible to create a win-win-win scenario where agribusiness and small scale farmers coexist and equally benefit. As clearly underlined by Oliver De Schutter (2011), the UN Special Rapporteur on the Right to Food, this scenario of coexistence is unsustainable and, even when it does not imply direct grabbing or violent evictions, leads to marginalization and exclusion of the small farmers in the long term (Ferrando, 2014).

\footnotetext{
12 The technical name of the 'Masterplan' is 'Support Agriculture Development Master Plan in the Nacala Corridor in Mozambique' (Prosavana-PD). The second report is available at http://www.grain. org/article/entries/4703-leaked-prosavana-master-plan-confirms-worst-fears.

${ }^{13}$ Master Plan, ibid, pp. 4-59.

${ }^{14}$ Ibid.
} 
Finally, ProSavana will produce other "silent" or "virtual land grabbing" (McCarthy et al., 2012), which will be masked behind the process of land titling, the transition from the current agricultural system to that of "settled agriculture" and the increase in the areas of "contract farming." Differently from occupations and evictions, which will be visible and a rather easy target for protests, these other forms of territorial occupation will represent a more subtle way of "opening a country," 15 a transformation of Mozambican territory from below.

In the case of the land titling process, the whole mechanism of attributing and defining borders through the allocation of the rights to use and profit from the land (DUAT) ${ }_{16}^{16}$ is proposed as means to "facilitate the identification of areas for the promotion of agriculture by large farmers, private companies and medium scale farmers with leading experience." ${ }^{17}$ Titling becomes as the first step in the transition to intensive agriculture. As it is proposed, the Plan aims at applying the highly criticized economic perspective proposed by De Soto's Mystery of Capital (2003) and the Western conception of private/public divide, in order to draw bright lines around each owner, and define territories for economic development.

Moreover, this process of formalization and definition of boundaries, which has been amply criticized for the destruction of existing pluralism ${ }^{18}$ and for the simplification determined by the mechanism of 'legibility' (Scott, 1999), is likely to negatively affect the local communities at least in three ways: a) people are likely to receive land on the basis of standards and parameters that they will hardly be able to produce, consult, and modify; b) formalization tends to crystallize the existing social dynamics against redistributive attempt and without taking into consideration the position of the weakest and socially marginalized; c) to close the circle, all the area which will not be titled will be considered public, eminent domain of the state that can be given in concession for large-scale farming.

Moving to 'settled farming' and 'contract farming' as the other two 'virtual grabbings', they are both described by the Master Plan and appear as top-down impositions of socio-economic transformations throughout the entire Corridor, where millions of people will be involved. Although these two cases cannot be seen as a form of explicit land grabbing as forced eviction, they certainly fall in the notion of grabbing as control and appropriation of the power to decide how land, water and labour are used now and in the future (Franco et al., 2013). In particu-

\footnotetext{
${ }^{15}$ Harvey (2003) writes that "The general thrust of any capitalistic logic of power is not that territories should be held back from capitalist development, but that they should be continuously opened up."

${ }^{16}$ It is interesting to notice that the project does not imply the distribution of property rights, but exclusively of land use rights.

${ }^{17}$ Master Plan, supra note 13, pp. 3-15.

18 The process of land titling has also been highly criticized because it is utilized by states as an instrument of securitization. More precisely, Scott (1999) writes that "the modern nation state organizes its subjects (including both people and things) in ways that makes (sic) them easier to govern - or 'visible' - by "rationalizing and standardizing what was a social hieroglyph into a legible and administratively more convenient format".
} 
lar, the two processes will generate a shift in the power relationships, create dependence from agro-industry, and increase the volatility of life given to the strong link with global market's prices.

Starting from the transition to "settled farming", the Plan affirms that it represents "an urgent need, in view of the rapid population growth and limitation in available farmland in the Nacala Corridor." ${ }^{19}$ However, what is lurking behind "settled farming" is much more than a "progress" toward higher production. It is a political decision embedded in the idea of entrepreneurial push to economic growth accompanied by an increase in private debt. As in the case of the Indian Green Revolution so clearly exposed by Raj Patel (2013), agriculture inputs and fertilizers, pesticides, machines, improved seeds (probably GMO) and a broader set of inputs will replace the existing agricultural structure, introducing a new form of dependency for the farmers, and increasing the turnout of the multinational enterprises which produce them. More subtly than a grabbing conduced by means of police, enclosures, and the fences, this 'virtual land grab' will be conducted by banks, which will appropriate part of the production value in the form of interest, and, as history teaches, also profit from failures and foreclosures.

And in those areas where contract farming will be implemented, the consequences in terms of autonomy, food sovereignty, accumulation of the value of the land, and independence of the farmers, risks not to be any better. According to the Plan, the contract farming schemes will be undertaken within the framework of large-scale agribusiness operations, with the intent to have small farmers shifting to the production of soya, cotton, tea and tobacco, which are four cash crops produced mainly (if not exclusively) for export and not for national consumption.

As the other aspects of the Plan, contract farming enters the scene as a topdown imposition aimed at implementing a mixed system of large corporate agriculture and small-scale livelihood, which has a lot of similarities with the old model of the Medieval latifundio, where people were paid on a monthly or annual basis to work on someone's land and to produce the crops that were required by the lord (in the Mozambican case, the market). The risk for failed harvests or for a sudden reduction of the global price of the commodity stays with the farmers who are part of the scheme, and who lose their autonomy and who stop to be farmers and become proletarian farm-workers. Rather than physically occupying their land, contract farming will be occupying the people's future and biodiversity, and open the doors to agro-fuel production and market-led agricultural policies.

In conclusion, if we adopt a power-based interpretation of land grabbing, ProSavana will undoubtedly be a source of multiple grabbing. It will force a radical transformation of the existing control over land, seeds, biodiversity, water, culture, etc. It will happen in part by means of direct occupation, but also through the 'innovation' of the legal (formalization of the land), agricultural (water and capital

${ }^{19}$ Master Plan (2012), supra note 13, pp. 3-20. 
intensive agriculture), and productive structures (settled and contract farming). Will Brasilia be responsible for that?

\section{b. Will it be a Brasilia-sponsored invasion of the Savannah by Brazilian investors?}

Despite the counter-narrative produced in Brazil, Japan, and Mozambique, there is evidence suggesting that Brazilian and Japanese capital are ready to profit from the 10 million hectares of the Nacala Corridor. This will not be an invasion in the style of the Medieval crusades, but a subtle occupation in the name of development and technological innovation, a radical change of the existing productive and social structure that will favour capitalist expansion and accumulation. ${ }^{20}$

Whether the occupation will be exclusively conducted by investors coming from the two partner countries, it is not easy to say. However, there are some elements that should not be underestimated. For example, there have been exploratory missions conduced by the Brazilian Development Agency and a series of Japanese visits to Mozambique (Mello, 2013), ${ }^{21}$ while there are no accounts of "business journey" organized by other countries in the same region. In addition, representatives of Brazilian industrial complexes have openly declared their interest in the "African Cerrado," like the Mato Grosso Association of Cotton Producers (Ampa), ${ }^{22}$ the Sugar-cane Industries of Brazil (Unica) ${ }^{23}$ and the Pinesso Group. ${ }^{24}$ Moreover, Deputy Luiz Nishimori, a member of the PSDB-PR, who led twenty Brazilian agribusiness in their exploratory mission of the Nacala Corridor (Mello, 2013), has recently revealed that ProSavana will be useful to provide Brazilian farmers who do not have enough land in Brazil with new areas where to practice technologically advanced agriculture. ${ }^{25}$ Mozambican land will thus become the space needed by the Brazilian administration to undertake the land reform which has not occurred at home, an out-of-state escape valve for a government which has not been able to overcome the internal pressures to maintain the latifundio.

\footnotetext{
${ }^{20}$ On the 'global power of seeds and science', and technology as an instrument to reproduce and expand the empire, cf.,., Jasanoff (2006).

${ }^{21}$ According to the author, in $2011 \mathrm{ABC}$ helped organizing a journey for a group of 40 entrepreneurs from the Cerrado belonging to the National Confederation of Agriculture (CAN).

${ }^{22} \mathrm{He}$ claimed that "Mozambique is a Mato Grosso in the middle of Africa, with land for free, with no environmental obstacles and a cheaper shipping cost to China" (Mello, 2013)

${ }^{23}$ Eduardo Leão de Sousa stated that "Africa has a great potential for ethanol, due to its vegetation and climate, which are similar to those of the Brazilian Northeast, especially in the Sub Saharan region. The vegetation of the Savannah resembles that of the Cerrado. Alcohol is certainly an opportunity there." Source: Schlesinger (2012).

${ }^{24}$ Ibid.

${ }^{25}$ The interview was released on February $13^{\text {th }}, 2013$, at Palavra Aberta. The document is available at http://farmlandgrab.org/post/view/21652.
} 
Moreover, the involvement of Brazilian diplomacy goes beyond the conclusion of the international agreement with Japan in 2009, and Brazilian public money is certainly involved in the realization of the project. Both the Brazilian Development Agency and Embrapa, two public institutions, participate in ProSavana, and the National Bank of Economic and Social Development (BNDES) has formally issued a US\$ 300 millions loan in favor of Mozambique, ${ }^{26}$ part of which (US\$ 80 million) will go back to the Brazilian pockets of Odebrecht International for the construction of the Nacala international airport. ${ }^{27}$ In addition, the Brazilian FGV Projeto has been hired as consultants and are raising private money for the ProSAVANA Development Initiative Fund, a private equity fund based in Luxembourg with a Fund Target return (IRR) of $12 \%$ p.a. ${ }^{28}$ As Brazilian, it is likely to look among Brazilian investors and agribusinesses.

Finally, Brasilia exercises a peculiar soft power, a form of control associated to hegemony rather than imperialism. At a surface level, this form of power is linked with the geographical similarities underlined by Claber Guarany, the coordinator of FGV Projetos, and to the superiority of Brazilian technology compared to the Mozambican one. At a deeper level, it involves the role of Brazil as a 'model of development to be emulated by other states, ${ }^{29}$ the rhetorical force of South-South partnerships, the possibility for Brazil to revitalize images of a common colonial past, and the cultural and linguistic proximity (Funada-Classens, 2012).

To conclude on this point, a deep and critical analysis of the entire picture suggests that Mozambican land will be occupied by foreign investments, both directly both through indirect mechanisms of contract farming and increased dependence on inputs and credit. In light of that, the claims of land grabbing and foreignization of land appear legitimate and justified. At the same time, it is evident that Brazil is playing a pivotal role in the establishment and consolidation of the project, mainly through its hard power, but also through the use of soft power, an instrument of hegemonic control which is often absent from the analysis of how emerging countries interact with the Global South. If land grabbing will take place, and if it will happen with the support of Brasilia, the only question left concerns

\footnotetext{
${ }^{26}$ On the real nature of Brazilian capital and on its internationalization through the action of the National Bank for Economic and Social Development (BNDES), see, e.g., Tautz et al., 2012a; Tautz et al., 2012b.

${ }^{27}$ According to Oderbrecht International own webpage, the rest of the money will be used to realize the Beira port, a crucial hub in the project of export-oriented agricultural development of the Nacala Corridor. Source: http://www.odebrecht.com/sala-imprensa/noticias/noticia-detalhes-303.

${ }^{28}$ Source: FGV Noticias, http://fgvnoticias.fgv.br/en/node/3065; OECD webpage, http://www.oecd.org/ forum/issues/NACALA \%20CORRIDOR\%20FUND-FGV\%20Projetos.pdf.

${ }^{29}$ Discussing inter-state relations, Arrighi and Silver (1999) affirm that "the supremacy [...] of a nation state $[\ldots]$ can manifest itself in two ways: as "domination" and as "intellectual and moral leadership". By virtue of its achievements, "a dominant state becomes "the model" for other states to emulate and thereby draws them into its own path of development".
} 
the apparent schizophrenia between the internal opposition to foreignization and the participation of Brazil in the global rush for the land.

\section{CONCLUSIONS: BRAZIL AND THE GLOBAL SOUTH'S ROLE IN THE SURVIVAL OF CAPITALISM}

In his essay on The Survival of Capitalism (1976), Henry Lefebvre interrogates the self-reproducing capacity of capitalism, and asks how capitalism was able to "attenuate (if not resolve) its internal contradictions for a century, and consequently, in the hundred years since the writing of Capital, it has succeeded in achieving 'growth'." In his answer, the French intellectual points at the occupation and production of space as the means for capitalist survival. Following a similar trajectory, von Apeldoorn et al. (2013) have recently listed the four steps that a state has to take in order to fully become a capitalist state: market creation, market correction, market direction and external representation.

By combining Lefebvre and von Apeldoorn's ideas to the internal and external attitude of Brasilia with regards to 'global land grabbing', I claim that the duality suddenly loses its apparent inconsistency, and appears as the manifestation of Brasilia's role in protecting, consolidating, and expanding capitalism within and outside the national territory. As I have demonstrated, the restriction to Foreign Direct Investments (FDIs) in land introduced with a 2009 opinion by the General Attorney Office (AGU) cannot be interpreted as an anti-capital accumulation measure, but rather represents a strategic move of the government to obtain political legitimacy, to reduce external competition to Brazilian agribusiness, and to strengthen the 'Brazilian champions' (especially in the agro-diesel sector). Similarly, the role of public and private Brazilian actors in the definition and economic support of ProSavana is a clear evidences of the 'representational' moment in the relationship state-capital nexus.

Thus, rather than being two inconsistent trajectories, the economic nationalism against foreign investors and the internationalization process are the two faces of the same government, as clearly appears from the minutes of the meeting held in the 'Casa Civil' in 2007..$^{30}$ In the day when the participants agreed on the need to reform the AGU opinion and impose limits to foreign ownership, they also discussed the possibility to transform large-scale production of agrofuels into a fundamental source of alternative energy, and agrofuel itself into a matter of national security. Since then, Brasilia has been opposing the grabbing of its own land by foreigners, and foreigners only, but has also been supporting large-scale investments in ethanol in the Cerrado (Oliveira, 2013) and has launched a process of external representation of national interests finalized to the control of land abroad.

\footnotetext{
${ }^{30}$ In 2007, the President of the 'Casa Civil' was the current President of the Brazilian Federation, Mrs. Dilma Rousseff. For more information about the 2007 meeting at the 'Casa Civil', see Wilkinson (2011).
} 
However, I think that the relevance of ProSavana goes beyond the sole exposition of the state-capital nexus and of the neo-colonial attitude of some BRICS and emerging countries. It reveals the fragility of the general rhetoric of South-South cooperation, shows the increasing competition for scarce resources, and exposes the 'territorial trap' (Agnew, 1994) in which accounts of capitalist expansion are still segregated.

First of all, ProSavana is not a Brazilian occupation of Mozambican territory through the deployment of the tools of the Brazilian State Mode of Production, but rather a joint effort conduced by the Brazilian and the Japanese governments. Such a situation, where Brasilia plays a fundamental role because of cultural proximity and technological know-how, clearly collides with the dominant rhetoric of SouthSouth cooperation as a different and alternative form of interaction as compared to North-South development. It also demonstrates that core countries have realized the importance to cooperate with semi-peripheral countries, and the advantages in terms of South-South relationships and level of public acceptability.

Secondly, the strong Brazilian interest behind ProSavana can be interpreted within the rising competition among emerging and traditional state actors. From a geo-strategic perspective, the occupation of land represents the occupation of power and the possibility to control scarce resources. The construction of Brazil as a capitalist state has to be coupled with the reinforcement of Brazil as a global player, in particular given the increase in the global dependence on alternative energy, and given the interest of Brazil in supporting ethanol and agro-fuels production.

Moreover, a critical approach to the 'roots' of global capitalism, suggests that the neo-colonial efforts conduced by Brasilia to open the Savannah are unlikely to generate a national virtuous circle of economic growth. First of all, the accumulation of cheap resources located in Mozambique will be conduced by transnational enterprises (like Monsanto, Cargill, etc.) whose headquarters are located outside the fiscal and legal jurisdiction of Brasilia. Secondly, even when Brazil-based enterprises will be involved, they would operate through subsidiaries and corporate schemes, and are likely to receive tax-breaks, subsidies, incentives, and a substantive reduction of their fiscal contribution. Finally, we should not commit the 'nationalist' mistake to identify capital with a nation: the mobility of capital, the possibility to acquire shares on the public market, and the unprecedented amount of FDIs received by Brazil in the last years, suggest that it would be mistaken to talk about Brazilian capital, but it would be more correct to talk about global capital and the different States that are actively involved in its reproduction. As discussed by Sutton (2013) and Callinicos (2009) each state exercises its authority in favor of capital, because it has lost the possibility to chose or differentiate among what is national and what is not.

To conclude, the apparent duality between the internal and external positions of Brasilia face to foreignization of land is the expression of the political and economic objective to protect capitalist expansion and economic growth. However, while it is clear that Mozambican farmers and Mozambican autonomy will be the losers, it is not so clear that Brazil and Brazilian population will be the winners. By subordinat- 
ing its state prerogatives to the needs and interests of global capital, Brasilia is utilizing authority and public money to favor enclosures and dispossessions, a massive accumulation of national and African resources which will hardly find their way to the bottom of the Brazilian society. To use a colorful image, it could be said that Brazil has been using the 'Kansas City Shuffle', ${ }^{31}$ i.e., is pointing its finger toward the grabbing of the Amazon and the foreign attack to national sovereignty so that, while everyone is looking there, it can protect national champions and export pro-agrofuel policies throughout the Global South. All of that, despite their consequences in terms of land concentration, environmental destruction, and socio-economic conflicts (Mançano Fernandes et al., 2010; Hoefle, 2013; Oliveira, 2013; Baletti, 2012).

\section{REFERENCES}

Agnew, John (1994) “The territorial trap: The geographical assumptions of international relations theory", Review of International Political Economy 1: 53-80.

Arrighi, Giovanni and Beverly Silver (1999) Chaos and Governance in the Modern World System, Minneapolis: University of Minnesota Press.

Baletti, Brenda (2012) "Ordenamento Territorial: Neo-developmentalism and the struggle for territory in the lower Brazilian Amazon", Journal of Peasant Studies 39: 573-598.

Callinicos, Alex (2009) Imperialism and Global Political Economy, Cambridge: Polity Press.

Cox, Robert (1987) Production, Power and World Order: Social Forces in the Making of History, New York: Columbia University Press.

Daimas Paiva, Frederico (2013) "ProSavana: Criticas e esclarecimentos", Agroanalisis, available at www.farmlandgrab.org/post/view/21929.

De Schutter, Olivier (2011) “The Green Rush: The Global Race for Farmland and the Rights of Land Users”, Harvard International Law Journal 52.

De Soto, Hernando (2002) The Mystery of Capital, New York: Basic Books.

Edelman, Marc (2013) "Messy hectares: questions about the epistemology of land grabbing data", Journal of Peasant Studies 40J: 485-501.

Ferrando, Tomaso (2014) "Law and the exclusionary essence of large-scale investments in Sub-Saharan land”, African Journal of Legal Studies, 6 (2-3): 315-335.

Franco, Jennifer et al. (2013) "The global land grab: A primer, revised edition”, TNI Agrarian Justice, Amsterdam.

Funada-Classen, Sayaka (2013) "Analysis of the discourse and background of the ProSAVANA programme in Mozambique - focusing on Japan's role”, Paper presented at the 2013 “Legal and Development Implications of International Land Acquisitions”, Kyoto.

Fundación Pensar (2011) “Documento de políticas publicas”, Buenos Aires, p. 5. Available at http:// fundacionpensar.org/wp-content/uploads/2011/03/Propiedad-extranjera-de-la-tierra.pdf.

Gerstenberger, Heidi (1973) “Zur Kritik der historischen Konstitution des bürgerlichen Staates", PROKLA, No. 8/9: 207-226

Harvey, David (2003) The New Imperialism, Oxford: Oxford University Press.

Hoefle, Scott (2013) "Beyond carbon colonialism: Frontier peasant livelihoods, spatial mobility and deforestation in the Brazilian Amazon", Critical Anthropology 33: 193-213.

Hosono, Akio (2012) “South-South/triangular cooperation and capacity development”, in H. Kato,

\footnotetext{
${ }^{31}$ The term has been given meaning by the movie Lucky Number Slevin, in which it is used to refer to a situation in which a combination of distraction and subterfuge causes the mark to turn their attention away from the plot which proceeds in the opposite direction. McGuigan, Paul (2006) Lucky Number Slevin.
} 
Hiroshi (eds), Scaling Up South-South and Triangular Cooperation, Tokyo: Japanese International Cooperation Agency.

Hosono, South-South/Triangular Cooperation and Capacity Development, in Kato, Hiroshi (eds), (2012) "Scaling Up South-South and Triangular Cooperation", Japanese International Cooperation Agency (JICA), Tokyo.

Jasanoff, Sheila (2006) “Biotechnology and Empire: The Global Power of Seeds and Science”, OISIRIS 21.

Kali Daiuto, Adriana and Ana Beatriz Almeida Lobo (2011) "Restrictions on the ownership of rural real estate property by foreigners", São Paulo: International Bar Association.

Lefebvre, Henri (1976) The Survival of Capitalism: Reproduction of the Relations of Production, London: Allison \& Busby.

Mançano Fernandes, Bernardo et al. (2010) "Agrofuel policies in Brazil: paradigmatic and territorial disputes", Journal of Peasant Studies 37: 793-819.

McCarthy, John et al. (2012) “Trajectories of land acquisition and enclosure: development schemes, virtual land grabs, and green acquisitions in Indonesia's Outer Islands", Journal of Peasant Studies 39(2): 523.

Mello, Fatima (2013) "O que quer o Brasil com o ProSavana?", ADECRU.

Neil Brenner and Stuart Elden (2009) "Henri Lefebvre on state, space, territory", International Political Sociology 1,3: 353-377.

Oliveira, Gustavo (2013) "Land regularization in Brazil and the global land grab", Development and Change 44: 261-283.

Oya, Carlos (2013) 'Methodological reflections on 'land grab' databases and the 'land grab' literature 'rush'”, Journal of Peasant Studies 40.

Patel, Raj (2013) “The long green revolution”, Journal Peasant Studies 40: 1-63.

Sassen, Saskia (2013a) "Land grabs today: feeding the disassembling of national territory", Globalizations 10: 25-46.

Sassen, Saskia (2013b) “When territory deborders territoriality", Territory Politics Governance 1: 2145.

Sauer, Sergio and Sergio Pereira Leite (2011) "Agrarian structure, foreign land ownership, and land value in Brazil", Paper presented at the International Conference on Global Land rabbing, University of Sussex.

Schlesinger, Sergio (2012) "Brazilian International cooperation and investments: The internationalization of ethanol and biodiesel”, Rio de Janeiro: FASE.

Scott, James (1999) Seeing Like a State: How Certain Schemes to Improve the Human Condition Have Failed, New Haven: Yale University Press.

Sutton, Alex (2013) "Towards an open Marxist theory of imperialism", Capitalism and Class 37: 217-237.

Tautz, Carlos et al. (2012a) "O BNDES e a reorganização do capitalismo brasileiro: um debate necessário”, available at http://www.riosvivos.org.br/arquivos/site_noticias_77225852.pdf

Tautz, Carlos et al. (2012b) "O grande agente da mudança: A expansão nacional e transnacional de Empresas Brasileiras por meio do BNDES”, available at http://www.br.boell.org/downloads/ tautz_pinto_fainguelernt.pdf.

Trubek, David, Diogo Coutinho and Mario Schapiro (2013) "Towards a new law and development: new state activism in Brazil and the challenge for legal institutions", University of Wisconsin Law Review, Legal Studies Research Paper Series Paper No. 1207, World Bank Legal Review.

Van Apeldoorn, Bastian et al. (2012) "The reconfiguration of the global state-capital nexus", Globalizations 9: 471-486.

Wilkinson, John et al. (2011) "El caso de Brasil", in FAO (2011) "Acaparamiento de tierras: Estudios de 17 países de América Latina y el Caribe", study presented at the seminar "Dinámicas en el mercado de la tierra en América Latina y El Caribe”, Santiago de Chile. 